\title{
多質点系モデルによる固体音領域の建物内振動伝搬特性の評価 THE EVALUATION OF THE VIBRATION PROPAGATION CHARACTERISTICS IN THE BUILDING OF THE STRUCTURE BORNE SOUND DOMAIN BY THE MULTI DEGREE OF FREEDOM SYSTEM
}

\author{
山岸邦彰*, 野路利 幸**, 岩本＼cjkstart毅***, 原田浩之**** \\ Kuniaki YAMAGISHI, Toshiyuki NOJI, Takeshi IWAMOTO \\ and Hiroyuki HARADA
}

\begin{abstract}
To obtain the basic characteristics of the vibration in the building many vibration measurements were carried out to devise a simple prediction method of the structure borne sound. In this paper, vibration measurements of the three buildings were carried out to construct the analysis model to predict how vibration input into the foundation amplifies it in each floor of the building, and a multi-degree-of-freedom system to simulate these measurement results were proposed. In addition, although some measures method for the structure borne sound was devised and it has been in use, the Tuned Mass Damper (TMD) which used the vibration of balconies and corridors as an idea of structure borne sound reduction tuned in the desired frequency were devised, and the effect were confirmed by the simulation using the proposed analysis model.
\end{abstract}

Keywords : $\quad$ Multi-Degree-of-Freedom System, Vibration Measurement, Vibration Propagation, Structure Borne Sound Transfer Function, Tuned Mass Damper

多質点系モデル，振動測定，振動伝播，固体伝搬音，伝達関数，同調質量ダンパー

\section{1. はじめに}

バブル経済崩壊以降の地価の大幅な下落, 工場跡地の遊休地の増大 等を背景として, 都市の中心市街地に集合住宅が建設されるケースが 多くなってきている。中心市街地には敷地に隣接して高度な交通網が 発達しており, 交通に伴う騒音・振動が集合住宅の居住性に影響を与 える可能性が高い。中でも地下鉄の通過にともない発生する固体伝搬 音（以下，固体音）は, 竣工後に問題となる場合が多く, また事後対 策が困難なことから, 建築の企画・設計段階での精度の高い予測およ び対策立案が重要となる。

これまでに固体音予測に関する研究がいくつか行われている。松田 ほか ${ }^{11}$ は, 建物内の固体音の幾何学的拡散による減衰と内部粘性によ る減衰から構成された予測式を提案している。また, 要素間のエネル ギーの平衡状態を解析して音圧レベルを推定する SEA 法 ${ }^{2} や$ 減衰が 大きい場合にも適用できる拡張 SEA 法 ${ }^{3)}$ 等が提案されている。これ らの方法は対象建物が複雑な構造でも対応できる利点がある。しかし， 建物内で発生する振動の重複反射を現象的に捉えたものではないた め, 振動モードの影響が強く現れる低振動数領域での適用には注意す る必要がある。一方, 建物内の上下振動の重複反射を評価できる方法 に縄岡ら ${ }^{4)}$ の方法がある。この方法は柱をバネ, 床を質点とする多
質点系モデルにより柱の振動性状を算定し, その結果を用いてスラブ 振動を有限要素法（以下，FEM）で解き, 室内の音圧レベルを予測す る方法である。実測值との整合性は高いが，解析の一部に FEM を利 用する等, 方法が簡易であるとまではいえない。建築企画段階では評 価に関わる時間が制限されていることが多く, 評価方法の簡易性も重 要な要件と考えている。

筆者らは固体音の簡易予測法の構築を目的として, 建物内の振動伝 搬特性を把握するための振動測定や解析を行い, 基礎資料の蓄積を行 ってきた例えば 5), 6),7)。これらの結果, 数 $10 \mathrm{~Hz} \sim 100 \mathrm{~Hz}$ 程度の振動数範 囲（以下，固体音領域）における建物内の振動伝搬特性を精度良く予 測するためには，柱・壁等の鉛直部材の振動特性に加えて，住戸内の スラブやバルコニー等の振動特性を反映させることが重要であり, 振 動論に基づく評価方法の確立が必要であると考えている。

本論では, 多質点系モデルを利用した建物内振動伝搬特性の簡易評 価方法の構築を目指す。はじめにスラブ等の上下振動を考慮した多質 点系モデルによる解析方法を展開寸る。次に， 3 棟の建物に対して行 った振動測定の概要および結果について示し,これらの実測結果から 算定される Fourier スペクトル比と，提示した評価法による伝達関数 との比較を行い，本評価方法の妥当性と問題点を明らかにする。

\footnotetext{
* 三井住友建設(侏)建築事業企画部 修士 (工学)

** 福井工業大学工学部建設工学科建築学専攻 教授 $\cdot$ 工博

*** 三井住友建設侏研究開発管理部 工修

**** 三井住友建設株建築研究開発部 博士 (工学)
}

Building Construction Marketing Planning Dept., Sumitomo Mitsui Construction Co., Ltd., M. Eng.

Prof., Dept. of Architecture and Civil Engineering, Fukui University of Technology, Dr. Eng. Research \& Development Administration Dept., Sumitomo Mitsui Construction Co., Ltd., M. Eng.

Building Construction Research \& Development Dept., Sumitomo Mitsui Construction Co., Ltd., Dr. Eng. 
一方, 予測した結果, 固体音による居住環境の悪化が懸念される場 合には適切な対策を講じる必要がある。これまでに固体音を低減する ための対策が種々考案され, 実用化されてきているが, 本論ではバル コニーや廊下等を同調質量ダンパー（以下，TMD）として利用する 固体音対策を検討寸る。ここでは, 提示した評価法を用いて, 質量比 および TMD の振動数をパラメータとして解析を行い, その効果につ いて論じる。

\section{2. 多質点系モデルを用いた上部構造の伝達関数の評価方法}

これまで行ってきた振動測定およびその数值シミュレーションの 結果から, 上部構造の上下方向の伝達特性は各階質量と鉛直支持部材 の鉛直剛性から求まる固有モードの影響を受けるだけでなく, 上下振 動が支配的なスラブ, バルコニーおよび廊下等（以下ではまとめてス ラブと呼ぶ）の振動の影響も強く受けていることが分かった。本章で は, 多質点系モデルを用いて, このようなスラブの振動特性を考虑に 入れた上部構造の伝達関数の評価方法を示す。こでいう上部構造の 伝達関数とは, 建物の柱際または壁際位置における最下階に対する各 階の絶対加速度の Fourier 振幅比をいう。対象とする振動成分は固体 音の発生に対して影響の大きい上下成分とする。

評価方法のフローを図 1 に示す。以下ではこのフローの各項目の詳 細について示す。

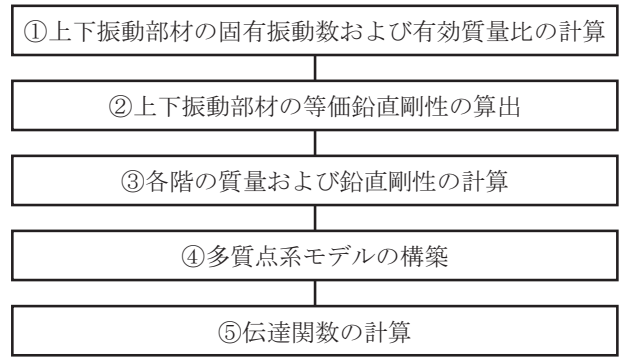

図 1 評価方法のフロー

\section{1 上下振動部材の固有振動数および有効質量比の計算}

居住部のスラブ (周辺梁を含む) や廊下等のように上下振動が支配 的な部材をここでは上下振動部材と呼ぶことにする。柱および壁等の 鉛直支持部材は含まない。上下振動部材としてはこの他に，二重床や 天井, キッチンカウンター等建築躯体ではない部位もあるが，ここで は比較的荷重の大きいスラブのみを対象とする。

一般に, スラブの固有振動数および有効質量比を精度よく計算する ためには, スラブの形状, スラブ厚, 大梁・小梁, 荷重等の諸条件を 詳細に考慮できる FEM 等による評価が有効であるが, 計算時間やス キルの問題から汎用性があるとは言えない。また, 固体音予測が求め られる事業企画段階では, 詳細な設計情報がないこと, 評価に多くの 時間を費やせないこと, 等の制約がある。そこで, スラブの形状を単 純化した矩形の梁付きスラブとして扱うことが現実的である。矩形の 梁付きスラブの固有振動数の計算方法は, 高畠ら ${ }^{8), 9,10)}$ によって示さ れている。本論では, 固有振動数の算定に同法を用いる。

スラブ振動に対する減衰の影響は小さいと考え, 振動方程式におけ る減衰項を無視すると, スラブの自由振動の振動方程式は式(1)のよ うに示される。

$$
m_{0} \frac{\partial^{2} w}{\partial t^{2}}+D_{0}\left(\frac{\partial^{4} w}{\partial x^{4}}+\frac{\partial^{4} w}{\partial y^{4}}+2 \frac{\partial^{4} w}{\partial x^{2} \partial y^{2}}\right)=0
$$

ここで, $m_{0}$ は単位面積当たりのスラブの質量, $w$ はたわみを表す。 $D_{0}$ はスラブの曲げ剛性であり， $E$ を Young 率， $h_{0}$ をスラブ厚さ， $v$ をPoisson 比とすると， $D_{0}$ は式(2)で表現される。

$$
D_{0}=\frac{E h_{0}{ }^{3}}{12\left(1-v^{2}\right)}
$$

たわみ $w$ は, 空間項と時間項とに変数分離し, さらに空間項を級 数展開して式(3)のように表現される。

$$
w(x, y, t)=\left[\sum_{m} \sum_{n} w_{m n} f_{m n}(x, y)\right] e^{i \omega t}
$$

ここに $w_{m n}$ は係数, $f_{m n}(x, y)$ は, $x$ 方向 $m$ 次, $y$ 方向 $n$ 次（以下, $m n$ 次）の形状関数であり, 近似的に式(4)で表現される。

$$
f_{m n}(x, y)=f_{m}(x) f_{n}(y)
$$

ここで， $f_{m}(x), f_{n}(y)$ はそれぞれ式(5), (6)で表現される。

$$
\begin{aligned}
f_{m}(x)= & q_{1 m}\left(\cos k_{m} x+\cosh k_{m} x\right)+q_{2 m}\left(\cos k_{m} x-\cosh k_{m} x\right) \\
& +q_{3 m}\left(\sin k_{m} x+\sinh k_{m} x\right)+q_{4 m}\left(\sin k_{m} x-\sinh k_{m} x\right) \\
f_{n}(y)= & q_{1 n}\left(\cos k_{n} y+\cosh k_{n} y\right)+q_{2 n}\left(\cos k_{n} y-\cosh k_{n} y\right) \\
& +q_{3 n}\left(\sin k_{n} y+\sinh k_{n} y\right)+q_{4 n}\left(\sin k_{n} y-\sinh k_{n} y\right)
\end{aligned}
$$

ここに, $q_{1 m}, q_{1 n}$ 等は周辺梁の境界条件により求まる係数である。式 (3)を式(1)に代入すると Galerkin 式(7)が得られる。

$$
\delta w_{m n}: \sum_{m} \sum_{n} w_{\overline{m n}}\left[A_{\bar{m} \bar{m} m}-\lambda^{2} B_{\overline{m n} m n}\right]=0
$$

ここで, $\omega_{m n}$ をスラブの $m n$ 次固有角振動数とすると, $A_{\overline{m n} m n}, B_{\overline{m n} m n}$, $\lambda_{m n}{ }^{2}$ はそれぞれ式(8)〜(10)で表される。

$$
\begin{aligned}
& A_{\overline{m n} m n}=\int_{0}^{l_{x} l_{y}} \int_{0}^{l_{y}}\left(\frac{\partial^{4} f_{m n}}{\partial x^{4}}+\frac{\partial^{4} f_{m n}}{\partial y^{4}}+2 \frac{\partial^{4} f_{m n}}{\partial x^{2} \partial y^{2}}\right) f_{\overline{m n}} d x d y \\
& B_{\overline{m n} m n}=\int_{0}^{l_{x} l_{y}} \int_{0} f_{m n} f_{\overline{m n}} d x d y \\
& \lambda_{m n}{ }^{2}=\frac{\omega_{m n}{ }^{2} m_{0}}{D_{0}}
\end{aligned}
$$

式(7)中の $A_{\overline{m n} m n}-\lambda^{2} B_{\overline{m n} m n}$ が 0 となるように収束演算を行うと, ス ラブの固有角振動数 $\omega_{m n}$ が求まり, 固有モードは近似的に $f_{m n}$ で表現さ れる。

以上の解法により, 任意の建物の一般階 $i$ 階において第 $k$ スラブの $m n$ 次モードの有効質量比 ( $k$ スラブの全質量に対寸る有効質量の比) $\operatorname{Rem}_{i k m n}$ は, 式(11)より求められる。

$$
\operatorname{Rem}_{i k m n}=\frac{\left\{\int_{0}^{l_{i k k}} \int_{0}^{l_{i k y}} f_{i k m n}(x, y) d x d y\right\}^{2}}{l_{i k x} l_{i k y} \int_{0}^{l_{i k x} l_{i k y}} \int_{0}^{l}\left\{f_{i k m n}(x, y)\right\}^{2} d x d y}
$$

ここに, $l_{i k x}, l_{i k y}$ はそれぞれ $i$ 階 $k$ スラブの $x, y$ 方向長さ, $f_{i k m n}(x, y)$ は $i$ 階 $k$ スラブの $m n$ 次形状関数を表す。本論では, $i$ 階の $k$ スラブの $m n$ 次モードの固有角振動数 $\omega_{i k m n}$ と有効質量比 $R^{2} m_{i k m n}$ は解析対象振動 数の範囲, 寸なわち固体音が問題となる $100 \mathrm{~Hz}(628 \mathrm{rad} / \mathrm{s})$ までを対 象と寸る。また, 少なくともスラブの 1 方向が偶数次モードとなる場 
合については, 有効質量比がほぼ 0 となるので, 有効質量比 $R^{2} m_{i k m n}$ を無視することにする。

\section{2 上下振動部材の等価鉛直剛性の算出}

以上で求まった $i$ 階 $k$ スラブ $m n$ 次モードの固有角振動数 $\omega_{i k m n}$ と有 効質量比 $\operatorname{Rem}_{i k m n}$ を用いて, バネマスによる多質点系モデルを構築す る。 $i$ 階 $k$ スラブの全質量を $M s_{i k}$ とすると, $i$ 階 $k$ スラブ $m n$ 次モード の等価鉛直剛性 $k s_{i k m n}$ は式(12)で表現することができる。

$$
k s_{i k m n}=M s_{i k} \cdot \operatorname{Rem}_{i k m n} \cdot \omega_{i k m n}{ }^{2}
$$

\section{3 各階の質量および鉛直剛性の計算}

図 2 に示寸ような断面を考える場合には, 建物の一般的な地震応答 解析におけるモデル化の方法と同様に, 各階床に集中質点を設定する。 集中質点の質量 $m_{i}$ は, 各階の階高の中心間で囲まれた部分の躯体お よびその他の部位の全質量 $m_{\text {alli }}, \quad 2.1$ 節で計算される有効質量比 $R_{\text {Rem }}$ ikmn を利用して式(13)により算定される。

$$
\begin{gathered}
m_{i}=m_{\text {alli }}-\sum_{k}^{N_{s i}} M s_{i k} \sum_{m}^{N_{i k m}} \sum_{n}^{N_{i k n}} \operatorname{Rem}_{i k m n} \\
m=\{1,3,5, \cdots\}, \quad n=\{1,3,5, \cdots\}\}
\end{gathered}
$$

ここに, $N s_{i}$ は $i$ 階の計算対象とするスラブ総数, $N_{i k m}$ および $N_{i k n}$ は $k$ スラブの $x$ および $y$ 方向の計算対象とすべき最高次モード次数であ る。なお, 前述の理由から $m, n$ は奇数であり, 以降に示寸数式にお いても同様とする。 $i$ 階, $i-1$ 階間の鉛直剛性 $k v_{i, i-1}$ は, 階高 $H_{i}$, 鉛直支 持部材の断面積 $A_{i}$ および部材の Young 率 $E_{i}$ から式(14)で計算される。

$$
k v_{i, i-1}=\frac{E_{i} A_{i}}{H_{i}}
$$

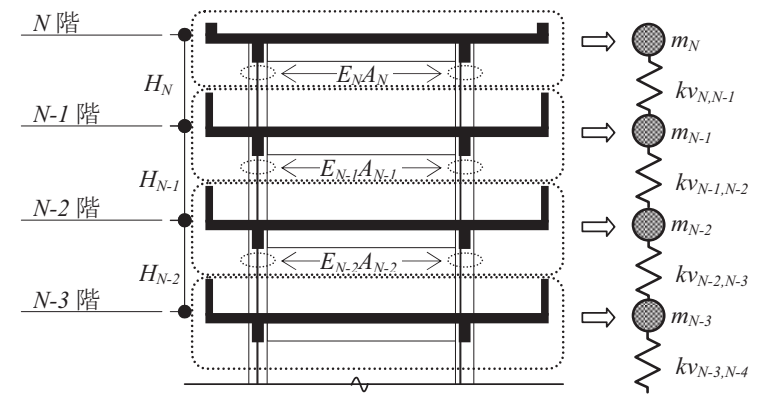

図 2 集中質点および鉛直剛性の計算方法

\section{4 多質点系モデルの構築}

図 3 に多質点系モデルの一般階におけるモデル図を示す。ここでは 最下階床に対する上層階床の伝達関数を評価するために, 最下階床を 固定としたモデルとする。 $i$ 階の集中質点（質量 $m_{i}$ ) に対して, 2.1 項および 2.2 項で算定された各スラブの各次等価鉛直ばねを介して対 応する各次等価質量が接続されている。図 3 より, 質点 $i$ における力 の釣合い式は式(15)となる。

$$
\begin{aligned}
& m_{i} \ddot{y}_{i}+\sum_{j}^{N} c_{i j} \dot{y}_{i}+\sum_{k}^{N s i} \sum_{m}^{N_{i k m m}} \sum_{n}^{N_{i k n}}\left(\dot{y}_{i}-\dot{y}_{i k m n}\right) c_{i k m n}+\left(y_{i}-y_{i-1}\right) k v_{i, i-1} \\
& +\left(y_{i}-y_{i+1}\right) k v_{i+1, i}+\sum_{k}^{N S i} \sum_{m}^{N_{i k m}} \sum_{n}^{N_{i k n}}\left(y_{i}-y_{i k m n}\right) k s_{i k m n}=-m_{i} \ddot{x}_{0}
\end{aligned}
$$

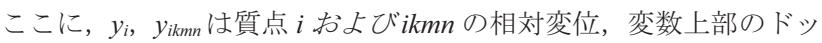
ト・は時間に関する 1 階微分, ・恫 2 階微分, $\ddot{x}_{0}$ は最下階の絶対加 速度, 他の変数については図 3 を参照されたい。

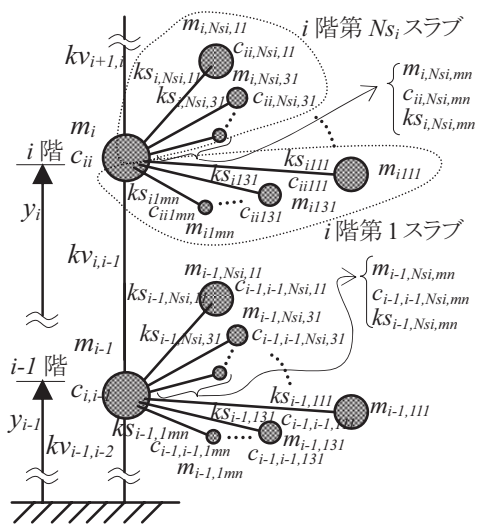

記号の説明

$y_{i}$ :質点 $i$ の相対変位

:質点 $i$ の質量

$m_{i k m n}: i$ 階 $k$ スラブ $m n$ 次有効質 量 $\left(=M s_{i k} \cdot \operatorname{Rem}_{i k m n}\right)$

$c_{i j} \quad$ : 質点 $j$ の相対速度が質点 $i$ に影響を及ぼす減衰係数

$c_{i i k m n}: i$ 階 $k$ スラブ $m n$ 次スラブ 振動系の減衰係数

$k v_{i} \quad: i$ 階と $i-1$ 階を結ぶ鉛直バ 市定数

$k s_{i k m n}: i$ 階 $k$ スラブ $m n$ 次スラブ 振動系の等価鉛直バネ定 数

図 3 多質点系モデルの一般階におけるモデル図

また，質点 ikmn における力の釣合い式は式(16)となる。なお，質 点系に置換されたスラブを以下ではスラブ振動系と呼ぶ。

$$
m_{i k m n} \ddot{i}_{i k m n}+\left(\dot{y}_{i k m n}-\dot{y}_{i}\right) c_{i k m n}+\left(y_{i k m n}-y_{i}\right) k s_{i k m n}=-m_{i k m n} \ddot{x}_{0}
$$

相対変位 $y_{i}, y_{i k m n}$ および最下階絶対加速度 $\ddot{x}_{0}$ の Fourier 変換表示を $Y_{i}, Y_{i k m n}$ および $\ddot{X}_{0}$ すると，式(15),(16)はそれぞれ式(17),(18)となる。

$$
\begin{aligned}
& -m_{i} \omega^{2} Y_{i}+i \omega\left\{\sum_{j}^{N}\left(c_{i j}+\delta_{i j} \sum_{k}^{N s i} \sum_{m}^{N_{i k m n}} \sum_{n}^{N_{i k n}} c_{i k k m n}\right) Y_{j}\right\} \\
& +\left(k v_{i, i-1}+k v_{i+1, i}+\sum_{k}^{N s i} \sum_{m}^{N_{i k m n}} \sum_{n}^{N_{i k n}} k s_{i k m n}\right) Y_{i}-\left(k v_{i, i-1} Y_{i-1}+k v_{i+1, i} Y_{i+1}\right) \\
& -\sum_{k}^{N s i} \sum_{m}^{N_{i k m}} \sum_{n}^{N_{i k n}}\left(k s_{i k m n}+i \omega c_{i k m n}\right) Y_{i k m n}=-m_{i} \ddot{X}_{0} \\
& -m_{i k m n} \omega^{2} Y_{i k m n}+i \omega\left(Y_{i k m n}-Y_{i}\right) c_{i k k m n}+\left(Y_{i k m n}-Y_{i}\right) k s_{i k m n}=-m_{i k m n} \ddot{X}_{0}
\end{aligned}
$$

ここに， $\delta_{i j}$ は Kroneckerのデルタである。

式(18)から $Y_{i k m n}$ は式(19)のように求められる。

$$
Y_{i k m n}=\frac{\left(k s_{i k m n}+i \omega c_{i k m n}\right) Y_{i}-m_{i k m n} \ddot{X}_{0}}{-m_{i k m n} \omega^{2}+i \omega c_{i k k m n}+k s_{i k m n}}
$$

式(19)を式(17)一代入すると, 式(17)は各階質点 $i$ の相対変位 $Y_{i}\{i=1,2, \cdots, N\}$ のみで表現される。すなわち, 仮に各階のスラブ数と 計算対象モード次数を同一と寸ると全質点数は $N \times N s_{i} \times N_{i k m} \times N_{i k n}$ $\left(=N N s_{i} N_{i k m} N_{i k n}\right)$ となり，一般的には $N N s_{i k} N_{i k m} N_{i k n} \times N N s_{i k} N_{i k m} N_{i k n}$ のマト リクスを計算する必要があるが，式(17)を利用すると， $N \times N$ のマト リクス計算で済むため計算時間を大幅に短縮することができる。

式(17)をマトリクスで表現すると式(20)となる。

$$
\left(-\omega^{2} \boldsymbol{M}+i \omega \boldsymbol{C}+\boldsymbol{K}\right) \boldsymbol{Y}=\boldsymbol{B} \ddot{X}_{0}
$$

ここに，
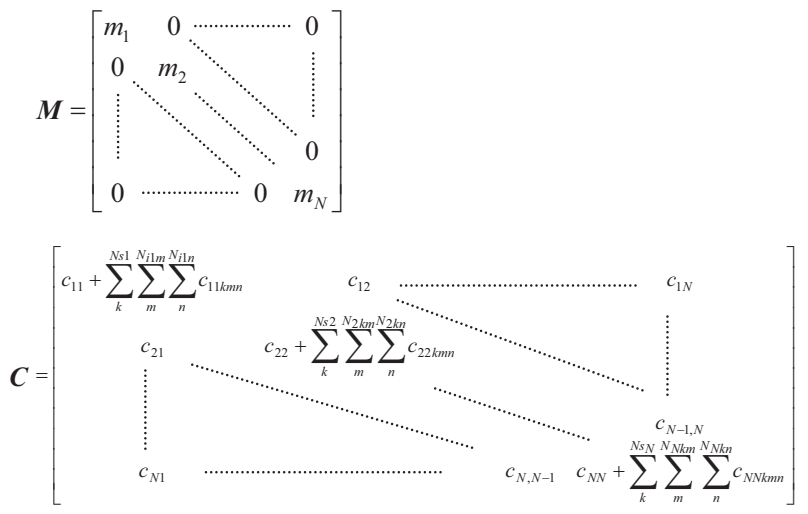


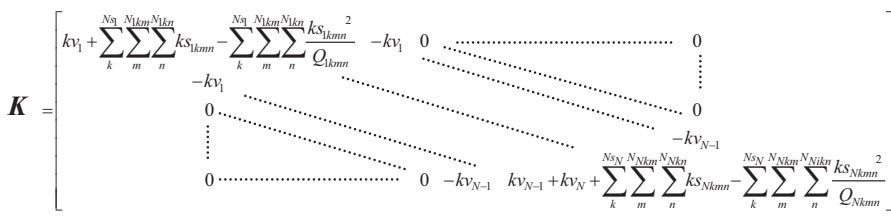

(23)

$$
\begin{aligned}
& \boldsymbol{B}=\left[\begin{array}{c}
-m_{1}-\sum_{k}^{N_{S}} \sum_{m}^{N_{1 k m m}} \sum_{n}^{N_{1 k m}} \frac{m_{1 k m n} k s_{1 k m n}}{Q_{k k m n}} \\
-m_{2}-\sum_{k}^{N_{22}} \sum_{m}^{N_{2 k m \eta} \sum_{2 k n}} \sum_{n}^{\frac{m_{2 k m n} k s_{2 k m n}}{Q_{2 k m n}}} \\
\vdots \\
-m_{N}-\sum_{k}^{N_{S N}} \sum_{m}^{N_{N k m}} \sum_{n}^{N_{N k n}} \frac{m_{N k m n} k s_{N k m n}}{Q_{N k m n}}
\end{array}\right] \\
& \boldsymbol{Y}^{T}=\left\{\begin{array}{llll}
Y_{1} & Y_{2} & \cdots & Y_{N}
\end{array}\right\}
\end{aligned}
$$

また，減衰マトリクス $\mathrm{C}$ の要素は，式(27)と式(28)の合成による。 ここで式(27)は上下振動部材を除く上部構造系の減衰係数 $c_{i j}$ で, 比例 減衰系と仮定した非減衰固有ベクトルおよび各次モード減衰定数を もとに算定される ${ }^{11)}$ 。式(28)は $i$ 階 $k$ スラブ $m n$ 次モードの減衰係数 $c_{i i k m n}$ で, 減衰マトリクスの対角項に対してのみ与えられることになる。

$$
\begin{aligned}
& c_{i j}=\sum_{p=I}^{N} \frac{2_{p} h_{p} \omega m_{i} m_{j p} u_{i p} u_{j}}{{ }_{p} M} \\
& c_{i i k m n}=2 h_{i k m n} \omega_{i k m n} m_{i k m n}
\end{aligned}
$$

ここに, $h_{i k m n}$ および $\omega_{i k m n}$ は $i$ 階 $k$ スラブの $m n$ 次モードの減衰定数 および固有角振動数, ${ }_{p} h,{ }_{p} \omega$ はスラブ振動系を除いた上部構造系の $p$ 次モード減衰定数および $p$ 次固有角振動数, ${ }_{p} u_{i}, p u_{j}$ はそれぞれ $p$ 次 固有べクトルの $i, j$ 階の值, ${ }_{p} M$ は $p$ 次の一般化質量である。

式(20)から各階の相対変位ベクトル $\boldsymbol{Y}$ は式(29)で求められる。

$$
\boldsymbol{Y}=\left[-\omega^{2} \boldsymbol{M}+i \omega \boldsymbol{C}+\boldsymbol{K}\right]^{-1} \boldsymbol{B} \ddot{X}_{0}
$$

\section{5 伝達関数の計算}

式(29)から求まる各階の相対変位 $Y_{i}$ と最下階の絶対加速度 $\ddot{X}_{0}$ から, $i$ 階の上部構造の伝達関数 $T_{i}$ は式(30)で表現される。

$$
T_{i}=\frac{-\omega^{2} Y_{i}+\ddot{X}_{0}}{\ddot{X}_{0}}
$$

また, 最下階絶対加速度 $\ddot{X}_{0}$ を 1 に基準化し, 伝達関数 $T_{i}$ を絶対值 で表現すると，伝達関数の絶対值は最終的に式(31)となる。

$$
T_{i}=\left|-\omega^{2} Y_{i}+1\right|
$$

\section{3. 実測結果による評価方法の検証}

\section{1 振動測定概要}

式(31)から得られる上部構造の伝達関数を, 高・中・低層の 3 建物 の振動測定結果のシミュレーションに適用し, 妥当性を検証する。表 1 に測定を行った 3 建物の概要を示す。

図 4 に建物 $\mathrm{A}$ および建物 $\mathrm{B}$ と地下鉄函体との位置関係, およびピ ックアップの配置を示す。建物 $\mathrm{A}$ の基礎下端から $3.3 \mathrm{~m}$ 深さの位置に, また建物 B から $0.9 m$ 離れた場所に地下鉄の函体がある。

建物 $\mathrm{A}$ は平面が約 $10 \mathrm{~m} \times 8.3 \mathrm{~m}$ の $\mathrm{L}$ 字形をした 4 階建の低層集合住
表 1 測定した 3 建物の概要

\begin{tabular}{|l|c|c|c|}
\hline & 建物 $\mathrm{A}$ & 建物 $\mathrm{B}$ & 建物 C \\
\hline \hline 対象軌道 & 地下鉄軌道 & 地下鉄軌道 & 高架軌道 \\
\hline $\begin{array}{l}\text { 軌道と基礎との水平 } \\
\text { 距離 }\end{array}$ & $0.0 \mathrm{~m}$ & $0.9 \mathrm{~m}$ & $8.0 \mathrm{~m}$ \\
\hline 用途 & 集合住宅 & 集合住宅 & 事務所 \\
\hline 階数 & 地上 4 階 & 地上 14 階 & $\begin{array}{c}\text { 地上 } 8 \text { 階 } \\
\text { 地下 } 2 \text { 階 }\end{array}$ \\
\hline 構造種別 & RC 造 & RC 造 & SRC 造 \\
\hline 構造形式 & 壁式 & 壁付ラーメン & 壁付ラーメン \\
\hline 基礎形式 & 直接基礎 & $\begin{array}{c}\text { 杭基礎 } \\
\text { (杭長 } 20 \mathrm{~m} \text { ) }\end{array}$ & 直接基礎 \\
\hline 基礎底位置 & GL-1.7m & GL- $2.7 m$ & GL-6.4 m \\
\hline 基礎梁成 & $1.6 m$ & $2.8 m$ & 不明 \\
\hline
\end{tabular}

※1: 数値は測定時に行った実測等による推定值

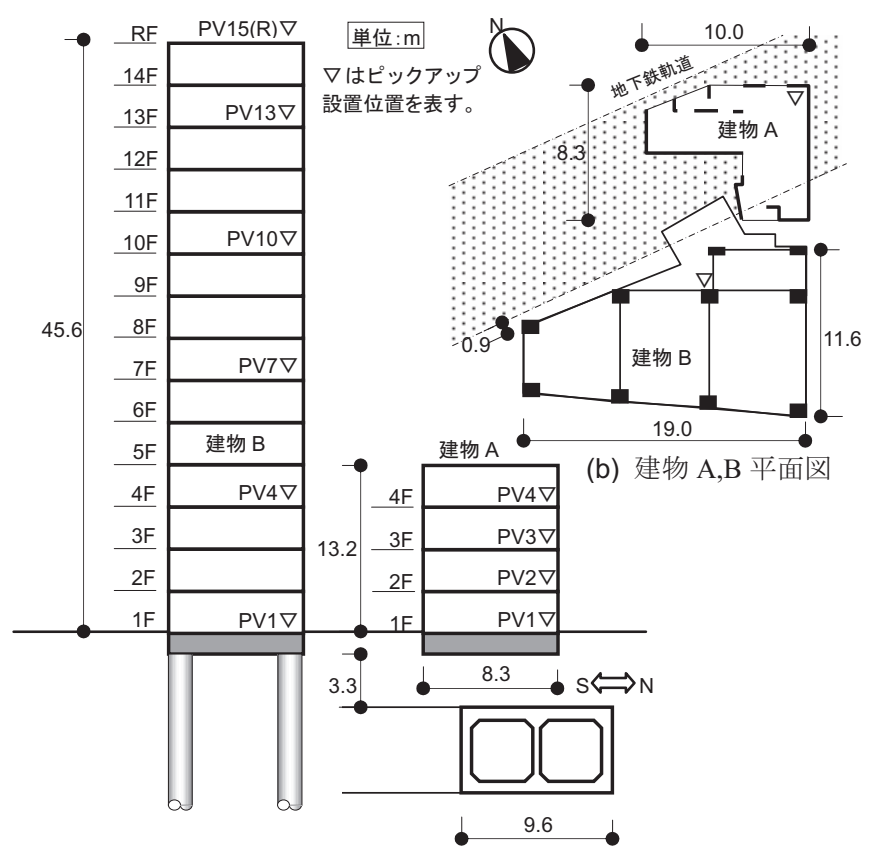

(a) 建物 A,B 断面図とピックアップ配置図

図 4 建物 A,B と地下鉄に関する概要図

宅である。構造種別は鉄筋コンクリート造（RC 造），構造形式は壁 式，基礎は直接基礎である。本建物は固体音対策として基礎直下に厚 さ $50 \mathrm{~mm}$ の防振用のゴムシートを全面に敷いている。測定当時は上棟 直後であり, 各室には仕上げ・設備等が設置されていない状況であっ た。建物 $\mathrm{A}$ は基礎梁を介して建物 $\mathrm{B}$ と慗がっている。測定には周波 数範囲が $\mathrm{DC} \sim 100 \mathrm{~Hz}$ の 1 成分サーボ型加速度計（IMV(侏製）を使用 した。ピックアップは各階に配置し, スラブ振動の影響の少ない壁の 入隅部に設置した。データはサンプリング周波数 $1 \mathrm{kHz}, \mathrm{A} / \mathrm{D}$ 変換は 16 bit で収録した。また，データ処理は地下鉄の通過時間約 $10 \sim 15$ 秒間を含めた約 16 秒間で Fourier スペクトル(バンド幅 $0.5 \mathrm{~Hz}$ の Parzen ウィンドウによる平滑処理を実施)を計算し, 各点間のスペクトル比 を計算した後, 良好な測定結果が得られたものに対してのみ相加平均 した。

建物 B は 14 階建の高層集合住宅で，約 $11.6 m \times 19 m$ のほぼ整形な 平面形状をなしている。構造種別は $\mathrm{RC}$ 造, 構造形式はラーメン, 基 礎は杭基礎(支持杭)である。建物 $\mathrm{B}$ も固体音対策として基礎直下に厚 さ $50 \mathrm{~mm}$ の防振用の発泡プラスチック系シートを全面に敷いている。 振動測定は竣工直前の状況で実施した。測定には周波数範囲が DC〜 $100 \mathrm{~Hz}$ の 1 成分加速度計(森ミットヨ製)を使用した。ピックアップは 一般階ではスラブ振動の影響の少ない柱際, 屋上階では柱直上の屋根 
仕上げ面上に設置した。データ処理についてはサンプリング周波数を $500 \mathrm{~Hz}$ とした以外は建物 A の処理条件と同一である。

図 5 に建物 $\mathrm{C}$ と地下鉄函体との位置関係およびピックアップの配 置図を示す。なお，建物と地下鉄に関する図面を入手することができ なかったため, 図中の寸法は実測等による推定值である。建物 C の 内部には地下鉄の出入り口があり, 約 $8.0 \mathrm{~m}$ 離れた場所に地下鉄函体 がある。建物 C は約 $16 m \times 10 m$ のほぼ長方形をした 8 階建の中層事 務所建築である。構造種別は SRC 造（非充腹）であり, 基礎形式は 未確認であるが基礎深度・地盤状況から直接基礎と推定される。測定 時には天井等の仕上げ材は存在していたが, 什器・備品等がない状況 であった。また, 対象建物は測定後間もなく解体され, 現在は存在し ない。測定システムおよびデータ処理は建物 A と同一である。

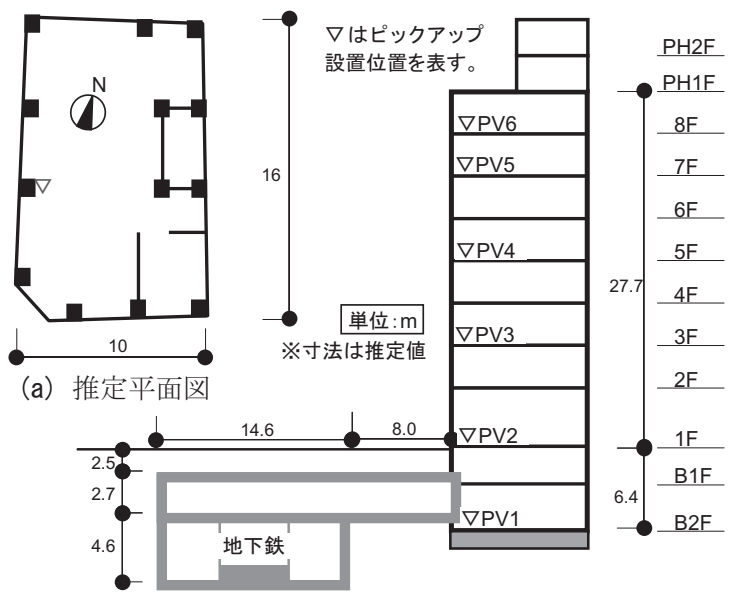

(b) 推定断面図

図 5 建物 C と地下鉄に関する概要図

\section{2 実測と解析による伝達関数の比較}

上部構造の伝達関数は, 実測では Fourier スペクトル比（以下，ス ペクトル比）の計算により, 解析では表 2 に示寸諸元を用いた多質点 系モデルから式(31)により計算する。以下, 解析モデルの構築方法に ついて概説する。

Young 率 $E_{i}$ は鉄筋コンクリート構造計算規準 ${ }^{12}$ によって求めたコ ンクリートの Young 率に静弾性係数に対する動弾性係数の比 ${ }^{13}$ とし て 1.3 を乗じたものと, 鋼材の Young 率 $2.1 \times 10^{5} \mathrm{~N} / \mathrm{mm}^{2}$ とをそれぞれ の部材断面積で重み付き平均した值とする。スラブ振動系のモデル化 は, 固有振動数が $100 \mathrm{~Hz}$ 以下で, 各階全質量に対寸る当該スラブの $m n$ 次モード有効質量比が 100 分の 1 以上のスラブのみ考慮した。減 衰定数 $h_{i k m n}$ については, 実測による応答倍率 $a^{7}$ を用いて $1 / 2 a$ により 減衰定数を評価寸ると約 0.03 であったことから, 全てのスラブ振動 系に対して一律に $h_{i k m n}=0.03$ とした。各質点の質量 $m_{i}$ は図 2 に示寸当 該体積にコンクリートの単位体積質量 $\gamma=2.4 t / m^{3} \quad$ (SRC 造の建物 C は $\left.\gamma=2.6 \mathrm{t} / \mathrm{m}^{3}\right)$ を乗じたものとし(建物 B, C では仕上げ質量を $0.1 \mathrm{t} / \mathrm{m}^{2}$ と 仮定して加算), 各層の鉛直剛性 $k v_{i, i-1}$ は雑壁等を無視した柱および壁 のみの水平断面積 $A_{i}$ から式(14)より計算した。スラブ振動系を除く全 体系の減衰定数は, これまでの測定結果のシミュレーション等から上 下方向 1 次モードに対する減衰定数 $h_{1}$ が 0.07 程度であったこと, 高 次モードになるに従い減衰定数がやや大きくなると考えられること を考慮して, 1 次から 4 次までの減衰定数 $\left(h_{1} \sim h_{4}\right)$ をそれぞれ 0.075 ,
$0.10,0.125,0.150$ とし, 5 次以上の減衰定数を 0.175 で一定とした。

表 2 多質点系モデル構築のための主な条件

\begin{tabular}{|c|c|c|c|c|c|c|}
\hline & 建物 A & 建物 B & 建物 $\mathrm{C}^{* 1}$ \\
\hline \multicolumn{4}{|c|}{$\begin{array}{l}\text { コンクリート設計 } \\
\text { 基準強度 } F c\left(N / \mathrm{mm}^{2}\right)\end{array}$} & 33 & 33 & 13.5 \\
\hline \multicolumn{4}{|c|}{ Young 率 $\left(\mathrm{N} / \mathrm{mm}^{2}\right)$} & $37.9 \times 10^{3}$ & $37.9 \times 10^{3}$ & $31.0 \times 10^{3}$ \\
\hline \multirow{2}{*}{\multicolumn{2}{|c|}{ 代表断面 }} & 柱( & & - & $950 \times 600$ & $550 \times 550$ \\
\hline & & 壁) & $(\mathrm{mm})$ & 200 & 180 & 150 \\
\hline \multicolumn{4}{|c|}{ スラブ厚 $(\mathrm{mm})$} & 200 & 200 & 150 \\
\hline \multirow{2}{*}{\multicolumn{4}{|c|}{$\begin{array}{l}\text { 各階質量の代表値 }(t) \\
\text { 各階剛性の代表値 } \\
(\mathrm{kN} / \mathrm{cm})\end{array}$}} & 73.5 & 192 & 185 \\
\hline & & & & 743.7 & 1,210 & 620.4 \\
\hline \multicolumn{4}{|c|}{ スラブ振動系の総数 } & 3 & 3 & 4 \\
\hline \multirow{4}{*}{\multicolumn{3}{|c|}{$\begin{array}{l}\text { スラブ振動系 } \\
\text { 有効質量 } \\
(t)\end{array}$}} & No.1 & 6.72 & 26.4 & 32.2 \\
\hline & & & No. 2 & 4.43 & 9.38 & 10.1 \\
\hline & & & No.3 & 0.894 & 3.69 & 3.09 \\
\hline & & & No.4 & - & - & 2.44 \\
\hline \multirow{4}{*}{\multicolumn{3}{|c|}{$\begin{array}{l}\text { スラブ振動系 } \\
\text { 固有振動数 } \\
(\mathrm{Hz})\end{array}$}} & No.1 & 39.0 & 41.3 & 10.6 \\
\hline & & & No. 2 & 65.7 & 58.1 & 17.9 \\
\hline & & & No.3 & 89.4 & 77.6 & 32.7 \\
\hline & & & No.4 & - & - & 53.1 \\
\hline & \multicolumn{3}{|c|}{$\begin{array}{l}\text { スラブ振動系を } \\
\text { 除く全体系 }\end{array}$} & \multicolumn{3}{|c|}{$h_{l}=0.075, h_{2}=0.100, h_{3}=0.125, h_{4}=0.150, h_{5} \sim=0.175$} \\
\hline & \multicolumn{3}{|c|}{ スラブ振動系 } & \multicolumn{3}{|c|}{0.03} \\
\hline \multicolumn{4}{|c|}{$\begin{array}{l}\text { モデル化に当たって } \\
\text { の特記事項 }\end{array}$} & $\begin{array}{l}\text { スラブ振動系固有 } \\
\text { 振動数は, 周辺 } \\
\text { 固定および単純 } \\
\text { 支持の各条件で } \\
\text { 計算された振動 } \\
\text { 数の平均值とし } \\
\text { た。 }\end{array}$ & $\begin{array}{l}\text { 同形状のスラブを } \\
\text { まとめ, } 3 \text { 種類のス } \\
\text { ラブ振動系を設置 } \\
\text { した。 }\end{array}$ & $\begin{array}{l}2 \text { 階の塔屋が存在 } \\
\text { するが,この部分 } \\
\text { の振動系を考慮 } \\
\text { せず,当該質量を } \\
\text { 屋上階の質量に } \\
\text { 加算している。 }\end{array}$ \\
\hline
\end{tabular}

※1: 数值は測定時に行った実測等による推定值

図 6 に建物 A における上部構造の伝達関数を実測結果と解析結果 とを比較して示す。また, 比較のためスラブ質点系を設置していない 場合の伝達関数も示す。なお, 実測では屋上階にピックアップを設置 していないため, 1 階に対する屋上階の伝達関数の実測值は示してい ない。実測に見られる約 $55 \mathrm{~Hz}$ の顕著なピークは解析でも認められる。 解析のピークは多質点系モデルの 1 次モードであることから, 実測結 果に見られる約 $55 \mathrm{~Hz}$ のピークは建物の上下方向の 1 次モード振動数 であると推定される。また, 実測結果に見られる $37,73 \mathrm{~Hz}$ 付近のや や小さなピークは, スラブ質点系を接続したモデルでは再現されるが, スラブ質点系を接続していない場合の解析では再現されない。これは, $39.0 \mathrm{~Hz}$ と $65.7 \mathrm{~Hz}$ に固有振動数を有するスラブ振動系の影響を受けて, これらの振動数において伝達関数が落ち込み, 逆にこれらの振動数の 前後で伝達関数にピークが生じたものと考えられる。すなわち, スラ ブ振動系が TMD としての挙動をしたため, それらの固有振動数付近 で伝達関数が低下していることが分かる。また, 各階質点には $89.4 \mathrm{~Hz}$ に固有振動数を有するスラブ質点系も接続されているが, 有効質量が 小さいためこの系による伝達関数の低減効果は軽微である。さらに, 実測と解析のピーク振幅はほぼ整合しており, 設定した 1 次モード減 衰定数 $h_{l}=0.075$ が概ね妥当であることが確認される。

図 7 に建物 B における上部構造の伝達関数を実測結果と解析結果 とを比較して示す。両者を比較すると約 $12 \mathrm{~Hz}$ の 1 次ピーク振動数お よび約 $33 \mathrm{~Hz}$ 付近の振幅の小さい 2 次ピークはほぼ一致している。し かし, これ以上の高振動数領域における伝達率は, 解析值は実測值を 下回っており, 必ずしもよく対応しているとはいえない。また，最上 階を除くと実測が概称 1〜2 となっているのに対して解析は 1 以下と なり, 実測が解析をかなり上回っている。また, 伝達率は異なるもの の最上階を除く両者の伝達率は, 凹凸はあるが上層階になるにしたが い一定の減少傾向が見られる。 


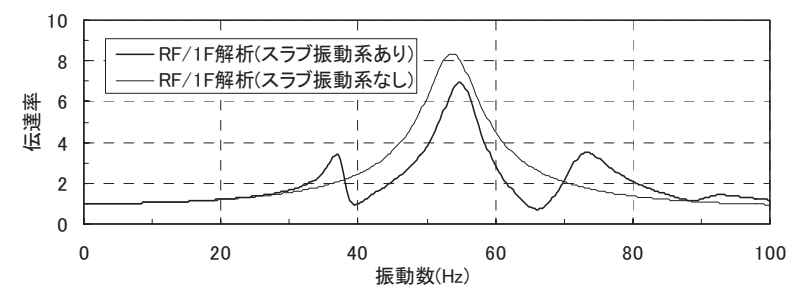

(a) 1 階に対する屋上階の上部構造伝達関数

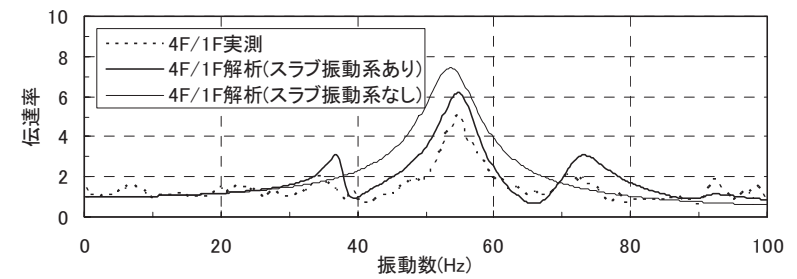

(b) 1 階に対する 4 階の上部構造伝達関数

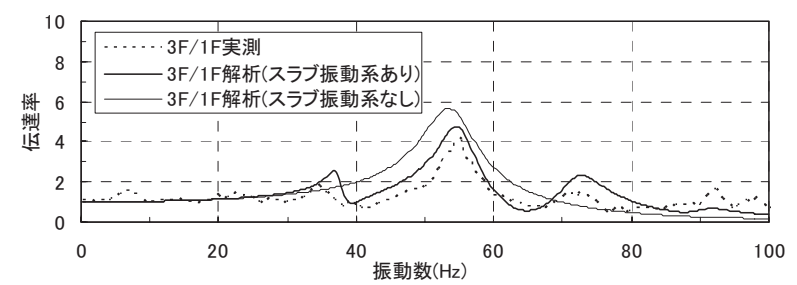

(c) 1 階に対する 3 階の上部構造伝達関数

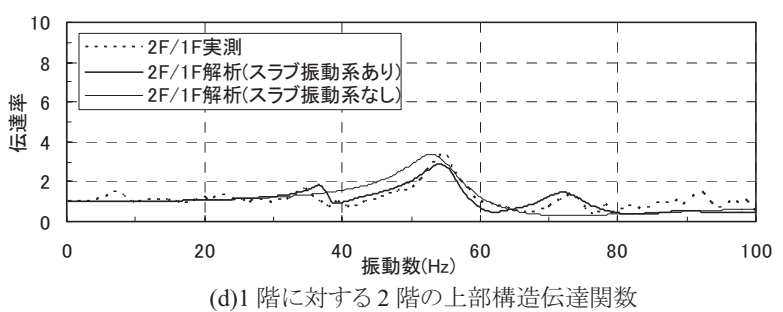

図 6 建物 $\mathrm{A} の$ 上部構造の伝達関数の実測值と解析值との比較

このことは, 建物 B のような条件の場合, 松田らの予測式における 内部粘性項の仮定が有意であると思われる。なお，図には示していな いが, 解析から求まる伝達率が実測より小さいことから, 本設定より 小さなモード減衰定数を設定して伝達関数を計算した。その結果, 各 次モード振動数のピーク值が大きくなるだけで, 明確なピークの見ら れない実測結果に示されるような伝達関数の傾向は見られなかった。 以上から, 高層建物である建物 $\mathrm{B}$ の多質点系モデルによる評価は, 約 30 数 $\mathrm{Hz}$ 以上の振動数領域で実測值と整合しないことが分かった。 この理由として, 建物 B には測定時に二重床や作り付けのキッチン, 収納棚等が設置されており,これらが上下振動部材として上部構造の 伝達関数に影響していると考えられる。ただし, 実測結果から伝達率 は最大でも 2 程度であり, 建物内の伝達率はそれ程大きくないことも 明らかになった。なお, 最上階で高振動数領域の伝達率が大きくなっ た理由として, 最上階の測定点が他点より柔らかい防水シート上であ ったことが原因であると推測される。

図 8 に建物 $\mathrm{C}$ における上部構造の伝達関数を実測結果と解析結果 とを比較して示す。他の建物より全体的に伝達関数が小さいため, グ ラフの最大值を $1 / 2$ に縮小して示す。実測結果に見られる $30 \mathrm{~Hz}$ 以下 の伝達関数の凹凸は解析結果でも概ね再現され, 比較的整合している。 しかしながら, $30 \mathrm{~Hz}$ 以上の振動数領域では, $35 \mathrm{~Hz}$ 付近や $50 \mathrm{~Hz}$ 付近 に見られるピークを解析では再現していない。

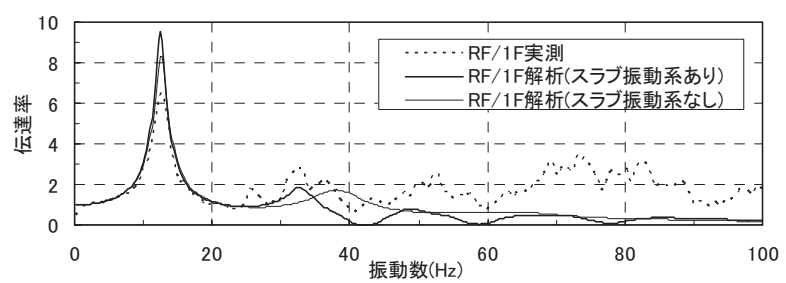

(a) 1 階に対する屋上階の上部構造伝達関数

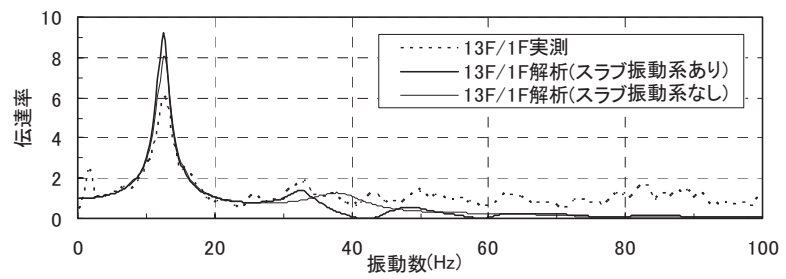

(b) 1 階に対する 13 階の上部構造伝達関数

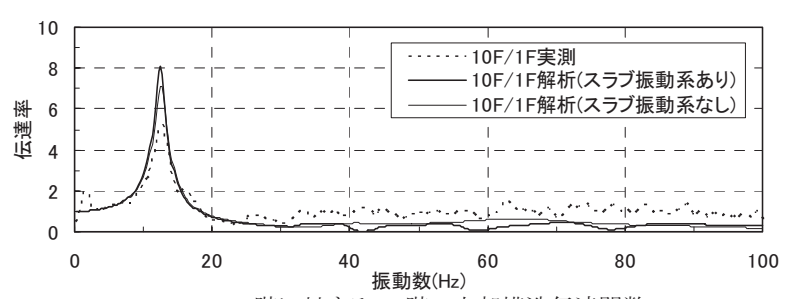

(c) 1 階に対する 10 階の上部構造伝達関数

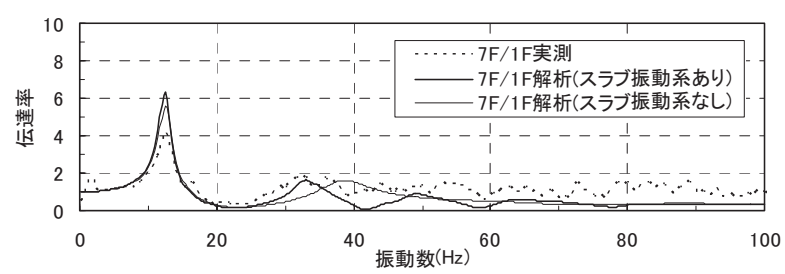

(d) 1 階に対する 7 階の上部構造伝達関数

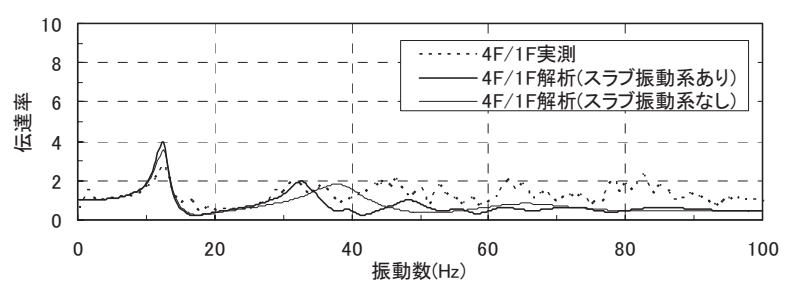

(e) 1 階に対する 4 階の上部構造伝達関数

図 7 建物 B の上部構造の伝達関数の実測值と解析值との比較

これは, 建物 C の寸法・材料定数の設定を推定断面で行っているモ デル化誤差が主原因であると思われる。スラブ振動系が接続されてい ない場合の 1,2 次モード振動数の解析結果はそれぞれ約 $15,43 \mathrm{~Hz}$ で あり，一般的に 2 次モード振動数が 1 次モード振動数に対して約 3 倍となっているのに対して, 実測に見られる 2 次モード振動数は $35 \mathrm{~Hz}$ 付近とかなり低い振動数になっている。このような現象は上部階に比 較的剛性の低い振動系が存在することで再現することができる。建物 Cの場合は, 最上階に設置された塔屋部分のモデル化が重要であると 考えられる。

また，建物 $\mathrm{C}$ は建物 $\mathrm{B}$ と異なり，実測結果において $50 \mathrm{~Hz}$ 以上の高 振動数領域では, 凹凸はあるものの伝達率が概ね 1 以下と小さくなっ ている。仕上げがないことが建物 B との大きな違いであり，仕上げ の有無により高振動数領域の伝達率が変わってくるものと推定され る。 


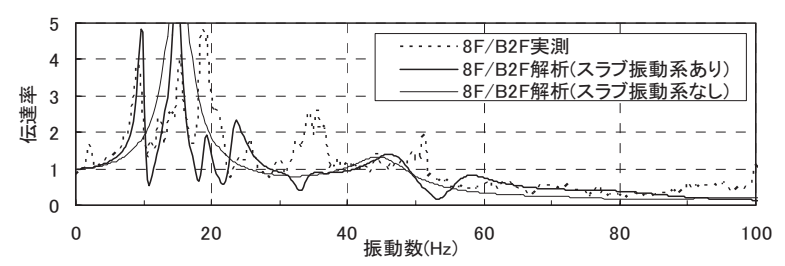

(a) 地下 2 階に対する 8 階の伝達関数

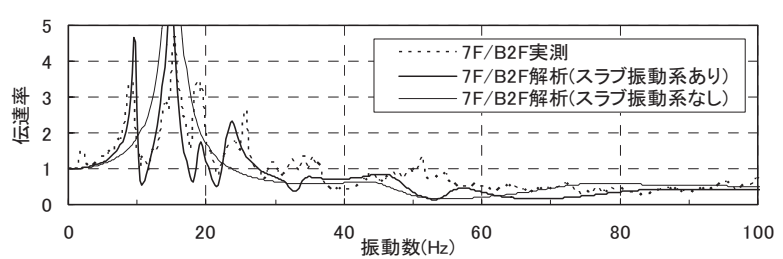

(b) 地下 2 階に対する 7 階の伝達関数

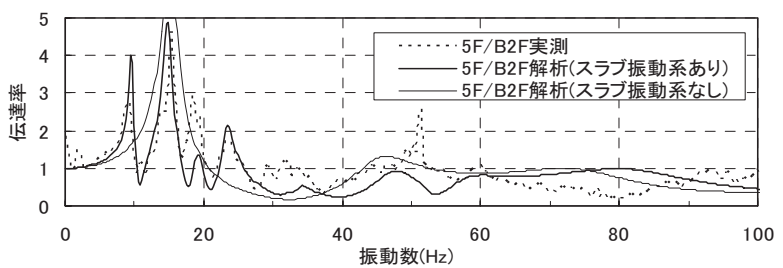

(c) 地下 2 階に対する 5 階の伝達関数

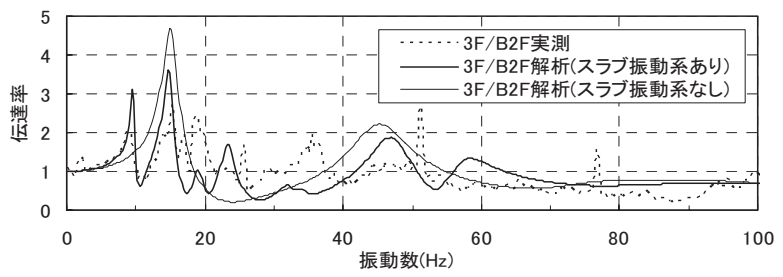

(d) 地下 2 階に対する 3 階の伝達関数

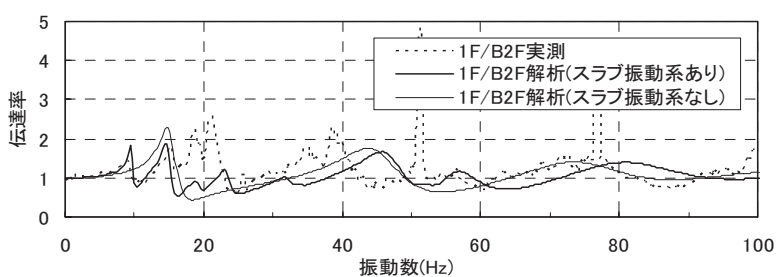

(e)地下 2 階に対する 1 階の伝達関数

図 8 建物 $\mathrm{C}$ の上部構造の伝達関数の実測值と解析值との比較

以上の結果から, 実測結果から得られる伝達関数にはスラブの上下 振動部材の振動が大きく影響しており, 多質点系モデルにより伝達関 数を算定する場合にはこれらの上下振動部材を適切に評価すること が重要である。3 建物の解析結果では, 低層建物である建物 $\mathrm{A}$ は $100 \mathrm{~Hz}$ 程度までは実測結果と良好に一致したが, 建物 B,C では高振動数側 で実測結果との整合性が取れていない。二重床等の仕上げや塔屋等, モデル化対象範囲の考え方およびそれらのモデル化が今後の課題で ある。また、本論では最下階床に対する各階床の伝達関数について検 討したが、固体音を予測するためには建物 $\mathrm{A}, \mathrm{B}$ に施工された防振シ 一トの影響や基礎の入力損失効果を適切に評価する必要がある。

\section{TMD 部材による伝達率低減効果に関する解析的検討}

前章のシミュレーション解析結果から, 上下振動部材の固有振動数 付近で伝達率が低下寸ることが分かった. 換言すれば, 上下振動部材 が TMD としての働きをしているとも言える。固体音低減対策として,
既に様々な方法が提案され実用に供されているが例えば 14)，上下振動部 材をTMD として働かせることにより伝達率を低減させることも有効 な手段であると考えられる。本章では，低層建物である建物 $\mathrm{A}$ を対 象として, 各階で TMD として働かせる上下振動部材（以下，TMD 部材）の質量比と TMD 部材の固有振動数（以下，TMD 振動数）を パラメータとして解析を行い, その低減効果を確認寸る。なお，ここ で想定している TMD 部材は, 集合住宅の共用部である廊下およびバ ルコニー等であり, 通常の TMD のように質量を付加することなく TMD 効果を期待できることに意義がある。

表 3 に TMD 部材のパラメータを示す。TMD 部材の固有振動数を 建物 $\mathrm{A}$ の上下方向の 1 次固有振動数である $55 \mathrm{~Hz}$ とし, TMD 部材の 有効質量比が当該階の全質量の $0.010,0.020,0.050,0.10$ のとなるよう に設定した（CASE1）。TMD 部材は各階に設置するものとし，TMD 部材の減衰定数を一律に $h_{T M D}=0.07$ とした。

図 9 にCASE1 の解析結果を示す。TMD 部材の有効質量比が大きく なるにしたがい, $55 \mathrm{~Hz}$ 付近にあった伝達関数のピークの減少が顕著 になり，TMD としての効果が見られる。しかし，TMD 部材を設置し たことにより, $37 \mathrm{~Hz}$ 付近と $48 \mathrm{~Hz}$ 付近の伝達関数が僅かながら大きく なり，TMD 部材の有効質量比が大きくなるほどその傾向が顕著であ る。そこで, TMD 振動数をこれらのピーク振動数に相当する $37,48 \mathrm{~Hz}$ に同調させた TMD 部材を設置したモデルを構築する。表 4 に解析ケ ースおよび解析パラメータを示す。TMD 振動数を $48 \mathrm{~Hz}$ と $55 \mathrm{~Hz}$ に設 定した $2 つ の \mathrm{TMD}$ 部材を設置した解析ケースをCASE2, さらに TMD 振動数を $37 \mathrm{~Hz}$ に設定した TMD 部材を設置した解析ケースを CASE3 とする。各ケースの TMD 部材の有効質量比の和は CASE1 と同じ $0.010,0.020,0.050,0.10$ とした。CASE2 は TMD 振動数 $48 \mathrm{~Hz}$ の有効質 量比が, また CASE3 は TMD 振動数 37, $48 \mathrm{~Hz}$ の有効質量比の和が, TMD 振動数 $55 \mathrm{~Hz}$ の有効質量比に対してそれぞれ一律に $1 / 2$ となるよ うに設定した。

表 3 TMD 部材の設定パラメータ(CASE1)

\begin{tabular}{|c|c|c|c|c|c|c|}
\multirow{2}{*}{ CASE 名 } & 各階 TMD & \multirow{2}{*}{ TMD 部材 } & \multicolumn{5}{|c|}{ TMD 部材の有効質量比 } \\
\cline { 4 - 7 } & 部材数 & 振動数 $(\mathrm{Hz})$ & (a) & (b) & (c) & (d) \\
\hline CASE1 & 1 & 55 & 0.010 & 0.020 & 0.050 & 0.10 \\
\hline
\end{tabular}

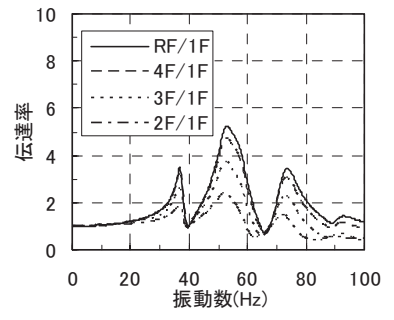

(a)有効質量比 0.010

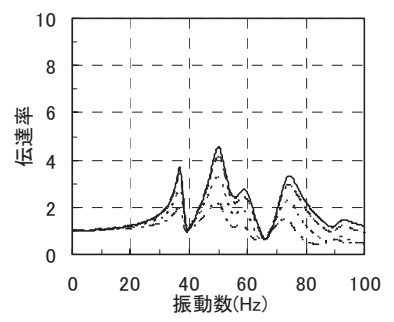

(c)有効質量比 0.050

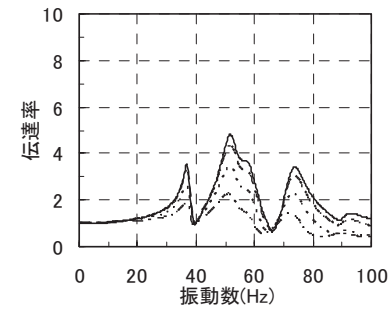

(b) 有効質量比 0.020

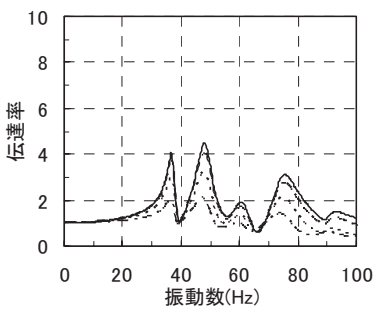

(d)有効質量比 0.10
図 9 伝達関数(CASE1) 
表 4 TMD 部材の設定パラメータ(CASE2,3)

\begin{tabular}{|c|c|c|c|c|c|c|}
\hline \multirow{2}{*}{ CASE 名 } & \multirow{2}{*}{$\begin{array}{l}\text { 各階 TMD } \\
\text { 部材数 }\end{array}$} & \multirow{2}{*}{$\begin{array}{c}\text { TMD 部材 } \\
\text { 振動数 }(H z)\end{array}$} & \multicolumn{4}{|c|}{ TMD 部材の有効質量比 } \\
\hline & & & (a) & (b) & (c) & (d) \\
\hline \multirow{2}{*}{ CASE2 } & \multirow{2}{*}{2} & 55 & 0.0067 & 0.013 & 0.033 & 0.067 \\
\hline & & 48 & 0.0033 & 0.067 & 0.017 & 0.033 \\
\hline \multirow{3}{*}{ CASE3 } & \multirow{3}{*}{3} & 55 & 0.0050 & 0.010 & 0.025 & 0.050 \\
\hline & & 48 & 0.0025 & 0.0050 & 0.013 & 0.025 \\
\hline & & 37 & 0.0025 & 0.0050 & 0.013 & 0.025 \\
\hline
\end{tabular}

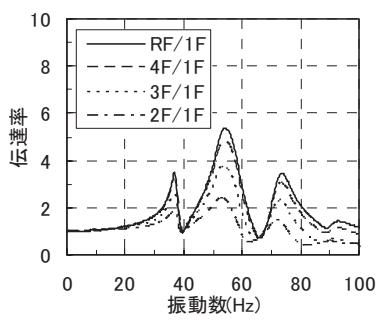

(a) 有効質量比 0.010

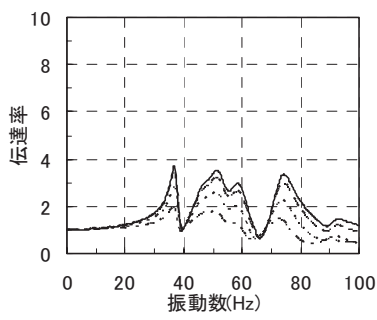

(c) 有効質量比 0.050

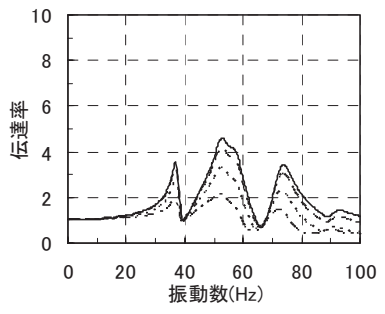

(b) 有効質量比 0.020

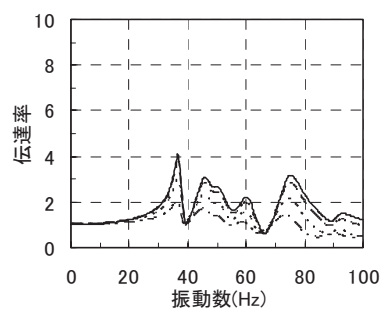

(d) 有効質量比 0.10
図 10 伝達関数(CASE2)

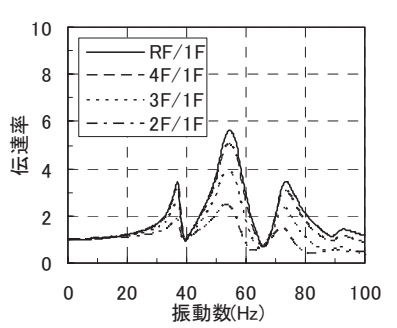

(a) 有効質量比 0.010

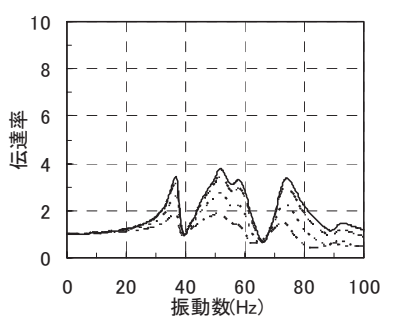

(c) 有効質量比 0.050

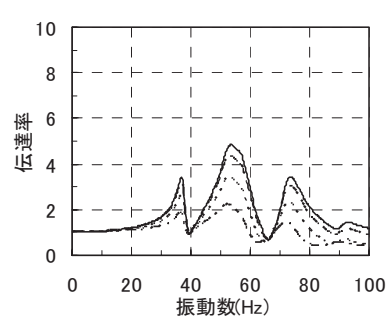

(b) 有効質量比 0.020

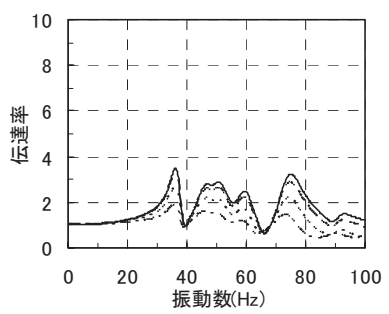

(d) 有効質量比 0.10
図 11 伝達関数(CASE3)

図 10 にCASE2, 図 11 にCASE3 の解析結果を示す。CASE1 と比 較して TMD 振動数が $55 \mathrm{~Hz}$ の TMD 部材の有効質量比が相対的に小さ くなったため, $55 \mathrm{~Hz}$ 付近の伝達関数の低減効果はやや小さくなるも のの, $37 \mathrm{~Hz}$ と $48 \mathrm{~Hz}$ 付近のピークが低減され, $40 \sim 60 \mathrm{~Hz}$ 付近の伝達 率は全体的に小さくなっている。特に, CASE3 で各階の有効質量比 が 0.10 の場合は, $100 \mathrm{~Hz}$ までの振動数領域で概ね伝達関数が 3 以下 となっている。

以上より, 適切な TMD 部材を設置することによる固体音領域での 伝達関数の低減効果が確認された。有効質量比が高く, かつ固有振動
数を変化させ得る廊下やバルコニーの TMD 化が実現化すれば, 固体 音対策の一方法として有用である。さらに, TMD 部材の固有振動数 を調整することができれば事後対策も可能になると考えられる。

\section{5. まとめ}

固体音領域における建物内の振動伝搬特性 (上部構造の上下方向の 伝達関数）の評価方法として, スラブ等の振動を考慮した多質点系モ デルを利用した評価方法を提示し，3建物の振動測定から得られた伝 達関数と本評価法により得られる伝達関数との比較を行った。その結 果, 低層建物については実測と解析から求まる伝達関数が概残整合し, 中高層建物については低振動数領域でのピーク振動数は概ね一致し た。これらのことから，上部構造の伝達関数を評価する場合に，スラ ブ等の上下振動部材の振動の影響を適切に考慮することが重要であ ることが分かった。ただし，中高層建物の高振動数領域では実測結果 と解析結果との整合が取れなかった。この原因としては, 本モデル化 では上下振動部材としてスラブ等の躯体部分のみを考慮したが, モデ ル化していない二重床等の仕上げや塔屋の振動が影響していること が考えられる。中高層建物の高振動数領域における伝達関数の評価に ついては次期の研究課題としたい。

また，スラブ等の上下振動部材には TMD としての効果があること から，低層建物を対象として TMD 部材を設置したときの伝達関数の 低減効果についてパラメータスタディを行った。その結果, 適切な TMD 振動数を設定することにより, 効果的に伝達率は低減され, TMD 部材の質量が大きくなるに従い, その効果が大きくなることが 分かった。

謝辞 : 本研究を進めるにあたり, 早稲田大学創造理工学部曾田五月也 教授, 名古屋大学澤田義博名誉教授には大変貴重な御意見, 御指導を 賜りました。また，本測定にあたり三井住友建設侏池原誠一氏，西関 正明氏，當内優氏，嶋田泰氏の多大なる御協力を得ました。ここに謝 意を表します。

\section{参考文献}

1) 松田由利ほか: 建物構造体中における固体音の伝搬性状, 日本音響学会 誌， 35 巻 11 号, pp.609-615, 1979 .

2) 入江良彦:SEA 法による固体伝搬音解析，音響学会誌, No.48, pp.433-444, 1992.

3) 峯村敦雄ほか: 拡張 SEA を用いた建物内固体伝搬音の予測方法と適用 例，日本建築学会計画系論文集，第 461 号, pp.17-23, 1994.7 .

4) 縄岡好人ほか: 電車固体音の予測に関寸る研究（その 1）地下鉄固体音 の建物内伝搬，日本音響学会講演論文集,pp.723-733, 1991.10.

5) 山岸邦彰ほか：鉄道軌道に近接する免震建物の振動伝搬特性一（その 1) 地盤における振動伝搬特性, 日本建築学会大会学術講演梗概集, D-1 分 冊, pp.257-258, 2004.

6) 山岸邦彰ほか: 実測による地下鉄振動の建物内振動伝搬特性に関する研 究, 日本建築学会大会学術講演梗概集, D-1 分冊, pp.217-218, 2005.

7) 山岸邦彰ほか: 実測による地下鉄振動の建物内振動伝搬特性に関する研 究一(その 2) 直接基礎を有する壁式構造の評価結果, 日本建築学会大 会学術講演梗概集, D-1 分冊, pp.191-192, 2006.

8) 流田豊, 高畠秀雄ほか : 境界バネ及び中間支持を持つ梁の形状関数につ いて, 日本建築学会大会学術講演梗概集, B-1 分冊, pp.327-328, 1996.9.

9) 岡富邦広，高畠秀雄ほか：境界梁を持つスラブの簡易解析 その 2 固 有振動数, 日本建築学会大会学術講演梗概集, B-1 分冊, pp.331-332, 1996.9 .

10) 山岸邦彰, 船水則行, 高畠秀雄 : 床スラブの簡易解析法とその応用, 計 算工学講演会論文集 Vol.2, pp.19-22, 1997.5.

11) 柴田明徳：最新耐震構造解析 森北出版 1981.

12）日本建築学会 : 鉄筋コンクリート構造計算規準・同解説 1999.

13) 三谷勝之ほか: コンクリートはりの静弾性係数と動弾性係数に関する実 験, 日本建築学会大会学術講演梗概集, pp.39-40.1969.8.

14) 吉岡修: 鉄道振動の防止対策法, 日本音響学会誌, 55 巻 6 号, pp.455-460, 1999. 